\title{
sciendo
}

\section{ASSOCIATION OF MTNR1A AND CYP19 GENES POLYMORPHISMS WITH SPERM QUALITY AND TESTICULAR SIZE IN SANJABI BREED RAMS*}

\author{
Somayeh Kianpoor ${ }^{1}$ Alireza Abdolmohammadi ${ }^{1}$, Hadi Hajarian ${ }^{1}$, Zahra Nikousefat ${ }^{2}$, \\ Hasan Khamisabadi ${ }^{3}$ \\ ${ }^{1}$ Campus of Agriculture and Natural Resources, Razi University, Kermanshah, Iran \\ ${ }^{2}$ College of Veterinary Medicine, Razi University, Kermanshah, Iran \\ ${ }^{3}$ Agricultural and Natural Resources Research and Education Center, Kermanshah, Iran \\ •Corresponding author: alirezaam2006@gmail.com; alirezaam@razi.ac.ir
}

\begin{abstract}
The purpose of this study was to identify mutations in melatonin receptor $1 \mathrm{~A}(M T N R 1 A)$ and aromatase cytochrome P450 (CYP19) genes using PCR-RFLP technique and their associations with sperm quality and testicular size traits in Sanjabi breed rams. The blood and sperm samples were collected from Sanjabi rams $(n=96)$. Genomic DNA was extracted from the blood. A 824bp fragment from exon II of MTNR1A gene and a 517bp fragment from promoter 2 (P2) of CYP19 gene were amplified using two pairs of specific primers. The PCR products were separately digested by two restriction enzymes, SsiI for MTNR1A locus and DraI for CYP19 locus. Digestion by SsiI restriction enzyme resulted in $\mathrm{CC}, \mathrm{CA}$ and $\mathrm{AA}$ genotypes with frequency of $0.45,0.41$ and 0.14 , respectively. However, digestion of 517bp fragment of CYP19 gene by DraI endonuclease determined two AG and AA genotypes with frequency 0.89 and 0.11 , respectively. The Chi-square test proved that the two loci were in Hardy-Weinberg equilibrium (HWE). The significant effect was observed between different genotypes of MTNR1A gene and morphological trait $(\mathrm{P}<0.05)$ and there was a significant association between different genotypes of $C Y P 19$ gene and scrotal circumference trait $(\mathrm{P}<0.05)$. The results of this study indicated that polymorphisms of MTNR1A and CYP19 genes were not associated with most traits of sperm quality and testicular sizes. Therefore, it seems that further studies are needed to identify mutations in other regions of these genes and other genes responsible to genomic regions for the sperm quality and testicular size in Sanjabi ram in order to improve fertility in these herds.
\end{abstract}

Key words: CYP19 gene, MTNR1A gene, Sanjabi sheep, sperm quality, testicular size

Reproduction, as an important economic trait in sheep breeding, is a complex trait under effects of both genetic and environmental factors and has low (5-10\%)

*This study was financed from funds of Razi University, project No. 2361325. 
heritability (Javanmard et al., 2011). Most of the researches on fertility in farm animals have cleared many inclinations on the female side. Fertility in the male is as important as that in the female (Davidson and Farver, 1980). Rams with superior reproductive traits are required in order to increase fertility in herds, to improve the genetic merit and also to decrease the number of breeding males (Mukasa-Mugerwa and Ezaz, 1992). Production of large amount of high-quality spermatozoa by genetically superior rams has led to increase conception rates and to reduce the percentage of non-pregnant ewes and in general to improve overall flock fertility (Rege et al., 2000).

Survey of semen characteristics is one of the most effective factors for selecting breeding rams. The quality of semen is usually determined by sperm motility, volume, concentration, livability and morphological features (Mia et al., 2015). Direct selection for semen quality traits is difficult due to low heritability (Mathevon et al., 1998). However, the major genes associated with these traits can be used in breeding programs through marker-assisted selection (MAS). Selection of rams in herds based on DNA markers at an early age can reduce generation interval, increase selection accuracy and reduce cost of rams breeding in herds. Recently, researchers have focused on genetic background of ram fertility and the IGF-1 and leptin have been known as candidate genes affecting sperm quality of ram (Bakhtiar et al., $2017 \mathrm{a}$; b).

Melatonin receptor 1A (MTRN1A) and Aromatase cytochrome P450 (CYP19) are known as candidate genes for reproduction. Melatonin is released by the pineal gland during night. In sheep, short photoperiods which correspond to the highest melatonin secretion, positively effect the secretion of gonadotropin-releasing hormone $(\mathrm{GnRH})$ from hypothalamus and thus stimulate the secretion of luteinizing hormone (LH) (Malpaux et al., 1999). LH secretion is responsible for alternating presence or absence of ovulation in the female and for sperm production in the males (Malpaux et al., 1999). Melatonin stimulates testis for spermatogenic activity through increasing of Leydig cell sensitivity to LH (Langford et al., 1987). So far, in mammals, two specific melatonin receptors named $\mathrm{MT}_{1}$ and $\mathrm{MT}_{2}$ have been identified, but it seems that $\mathrm{MT}_{1}$ receptor may be involved to control reproductive activity (Pelletier et al., 2000). In sheep, MTRN1A gene is located at chromosome 26 (Messer et al., 1997) and includes two exons divided by a large intron (Reppert et al., 1994). Moreover, the exon II of this gene has shown a high degree of polymorphism in sheep populations (Pelletier et al., 2000).

In sheep, the CYP19 gene codifies aromatase P450 enzyme which is a terminal enzyme responsible for estrogen biosynthesis via conversion of androgens to estrogens (Simpson et al., 1994). Estrogen is an important hormone for controlling reproduction in male and female animals, fat deposition (Jones et al., 2000) and growth (Simpson et al., 2000). The CYP19 gene has been mapped on the ovine chromosome 7 (Goldammer et al., 1999). It is transcribed from four different promoter regions $\left(\mathrm{p}_{1.1}-\mathrm{p}_{1.4}-\mathrm{p}_{1.5}\right.$ and $\left.\mathrm{p}_{2}\right)$ depending on organs-specific activities but $\mathrm{P}_{2}$ is mainly active in granulosa cells (Vanselow et al., 2001). The purpose of this study was to identify polymorphisms of MTRN1A and CYP19 genes and their associations with semen quality and testicular size in Sanjabi breed sheep. 


\section{Animals and sampling}

\section{Material and methods}

Sanjabi sheep is the most important fat-tail meat sheep breed in the west region of Iran (Kermanshah province). In this study, blood and sperm samples were collected from 96 Sanjabi rams belonging to three large flocks (more than 400 heads of sheep) located in the province. At the same time, the dimensions of testis such as length, width and circumference were measured.

The flocks were under same management and housed in semi-extensive conditions with dry summer and cold winter. The grazing season generally lasted from April to October; animals were on pasture during the day and kept indoors at night. Supplemental feed, including alfalfa and barley grains, was offered to the animals. Annually, 30-40 rams were allocated randomly to mate with about $10-15$ ewes in breeding pens.

\section{Semen collection and evaluation}

Semen samples were collected from rams ( $2-5$ years old) using an artificial vagina in spring and autumn over two consecutive years. In order to increase accuracy of sperm evaluation, the rams were separated from flocks $24-48$ hours before sampling. Immediately after sampling, semen samples were evaluated for color, volume $(\mathrm{ml})$, mass motility (\%), progressive motility (\%) and sperm concentration $\left(\times 10^{7} \mathrm{sperm} /\right.$ $\mathrm{ml}$ ) according to Evans and Maxwell (1987). Smears related to morphology (\%), viability (\%), HOS and water tests (\%) were prepared and transferred to the laboratory for more evaluations. Sperm volume was directly recorded from the graduated collection tube and the concentration of sperm was determined using a hemocytometer. For assessing mass activity, $20 \mu 1$ of undiluted semen samples was transferred to a pre-warmed glass slide $\left(37^{\circ} \mathrm{C}\right)$ and examined under light microscope $(10 \mathrm{X})$, using scales from 0 (no motility) to 5 (excellent motility). Diluted semen samples (1:10) were placed $(10 \mu \mathrm{l})$ on a pre-warmed slid $\left(37^{\circ} \mathrm{C}\right)$ covered with cover slip to examine progressive motility under light microscope (40X). The eosin-nigrosine stained slides were evaluated for viability, where unstained spermatozoa were considered to be alive (Evans and Maxwell, 1987). The proportion of abnormal morphologically sperm was also determined by examining 200 spermatozoa in an eosin-nigrosine smear under microscope (40X). Total number of spermatozoa per ejaculate was calculated by multiplication of the seminal volume with the sperm density. Semen index (semen volume $\times$ sperm concentration $\times$ live sperm $\times$ progressive motility) was calculated as a semen quality indicator. The percentage of spermatozoa with plasma membrane integrity was determined using two methods including HOS (Revell and Mrode, 1994) and water test (Nur et al., 2005).

\section{DNA extraction, PCR reactions and samples genotyping}

Blood samples were taken from jugular vein of rams using sterile tubes containing EDTA as an anticoagulant. Genomic DNA was extracted from whole blood using DIAtom DNA prep100 kit (Gene Fanavaran Co, Iran), then quality and quantity of the extracted DNA samples were observed using $1 \%$ agarose gel electrophoreses and kept at $-20^{\circ} \mathrm{C}$ until they were used. The sequences of the specific primers to amplify 
MTNR1A and CYP19 genes are given in Table 1. Primers were synthesized by Metabion Company, Germany.

Table 1. Summary of general characteristics of primers and genes studied in this research

\begin{tabular}{|c|c|c|c|c|c|c|}
\hline Genes & Primer sequence & $\begin{array}{c}\text { Amplified } \\
\text { region }\end{array}$ & \begin{tabular}{|c} 
Product \\
size \\
(bp)
\end{tabular} & $\begin{array}{l}\text { Muta- } \\
\text { tion }\end{array}$ & $\begin{array}{l}\text { An- } \\
\text { nea- } \\
\text { ling } \\
\left({ }^{\circ} \mathrm{C}\right)\end{array}$ & $\begin{array}{l}\text { Restric- } \\
\text { tion } \\
\text { enzyme }\end{array}$ \\
\hline TTNRI & $\begin{array}{l}\text { F:5`-TGTGTTTGTGGTGAGCCTGG-3`’ } \\
\text { R:5`-ATGGAGAGGGTTTGCGTTTA-3` }\end{array}$ & exon II & 824 & C893A & 62 & SsiI \\
\hline CYP19 & $\begin{array}{l}\text { F:5'-ACAATGGGAGGCTCTGAGAATG-3' } \\
\text { R:5'-GAAAAATTAGAAAATCCCCAAAA-3' }\end{array}$ & $\begin{array}{c}\text { promoter2 } \\
\left(\mathrm{P}_{2}\right)\end{array}$ & 517 & $\mathrm{~A} 113 \mathrm{G}$ & 59 & DraI \\
\hline
\end{tabular}

PCR reaction was carried out in $25 \mu \mathrm{l}$ of final volume, containing 50-100ng of DNA used as a template, $0.25 \mu \mathrm{M}$ of each primer (Table 1), $2.5 \mu \mathrm{M}$ PCR buffer $1 \mathrm{X}$, $0.2 \mathrm{mM}$ dNTPs, $2.5 \mathrm{mM} \mathrm{MgCl}_{2}$ and $1 \mathrm{U}$ of Taq DNA polymerase. The amplification conditions for primers of the MTNR1A and CYP19 genes were as follows: an initial denaturation of $3 \mathrm{~min}$ at $94^{\circ} \mathrm{C}$, followed by 35 cycles of $30 \mathrm{sec}$ of denaturation at $94^{\circ} \mathrm{C}$, $30 \mathrm{sec}$ of annealing $\left(62^{\circ} \mathrm{C}\right.$ for MTNR $1 A$ locus, $59^{\circ} \mathrm{C}$ for $C Y P 19$ locus $), 1 \mathrm{~min}$ of extension at $72^{\circ} \mathrm{C}$ and final extension of $10 \mathrm{~min}$ at $72^{\circ} \mathrm{C}$. PCR products were electrophoresed on $1 \%$ agarose gel and DNA bands were visualized by ethidium bromide staining. The PCR products including of exon II of MTNR1A gene and promoter 2 (P2) of CYP19 gene were digested with SsiI and DraI restriction enzymes (Thermo Scientific, Germany), respectively. The digestion reactions were separately carried out in $15 \mu \mathrm{l}$ volume, containing $8 \mu \mathrm{l}$ of PCR products and $5 \mathrm{U}$ of SsiI or DraI enzymes. The reaction mixture was incubated at $37^{\circ} \mathrm{C}$ for $16 \mathrm{~h}$. Sample genotyping was conducted based on fragments separated by electrophoresis on $3 \%$ agarose and stained with ethidium bromide.

\section{Statistical analysis}

PopGene (Version 32) software (Yeh et al., 1999) was used to estimate allelic and genotype frequencies and heterozygosity. The Hardy-Weinberg equilibrium (HWE) was tested based on Chi-square test $\left(\chi^{2}\right)$. The association between different genotypes and traits studied was analyzed using GLM procedure of SAS package (Version 9.1) software (SAS Institute, 2004).

The linear model with the fixed effects was:

$$
y_{i j k l}=\mu+H Y S_{i}+W_{j}+A g e_{k}+G_{1}+e_{i j k l}
$$

where: $y_{i j k l}$ is the trait measured on each animal (semen quality and testicular size); $\mu$ is overall mean, $H Y S_{i}$ is the fixed effect of herd-year-season, $W_{\mathrm{j}}$ is the effect of ram weight (as covariate effect), $A g e_{k}$ is the fixed effect of ram age, $G_{1}$ is the effect of the $1^{\text {th }}$ genotypes, $e_{i j k l}$ is the residual effect. 
Least square means of the different genotypes were calculated by LSMEANS option in SAS software (Version 9.1) to determine the effects of these genes on semen quality and testicular size traits. The significant level of 0.05 was considered to show statistically significant differences for all comparisons.

\section{Results}

\section{PCR-RFLP and animal genotyping}

Genomic DNA quality of all samples was evaluated on 1\% agarose gels (Figure 1). The 824bp fragment for exon II of MTNR1A gene (GenBank U14109) was successfully amplified in all ram samples (Figure 2). The $\mathrm{A}>\mathrm{C}$ single nucleotide polymorphism (C893A) in the exon II of MTNR1A gene was detected by SsiI restriction enzyme, where the mutation led to Alanine by Aspartic acid substitution. Digestion of the amplified fragments by SsiI enzyme revealed three fragments (422, 218 and 184bp) for C allele (wild type) and two fragments (640 and 184bp) for A allele (mutant) (Figure 3). The allele and genotype frequencies of MTNR1A gene and Chisquare $\left(\chi^{2}\right)$ value have been presented in Table 2 . The frequencies of CC, CA and AA genotypes were $0.45,0.41$ and 0.14 and allelic frequencies of $\mathrm{C}$ and $\mathrm{A}$ alleles were 0.65 and 0.35 , respectively.

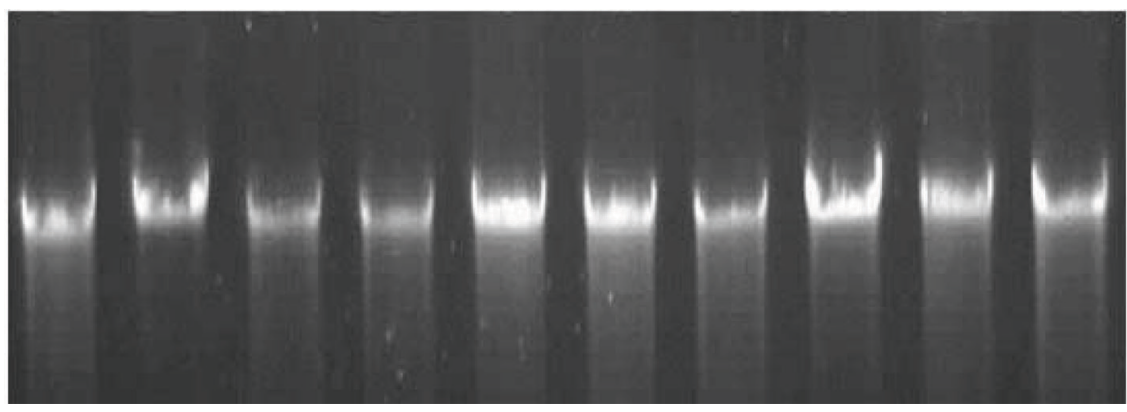

Figure 1. DNA extracted from blood of Sanjabi ram on $1 \%$ agarose gel

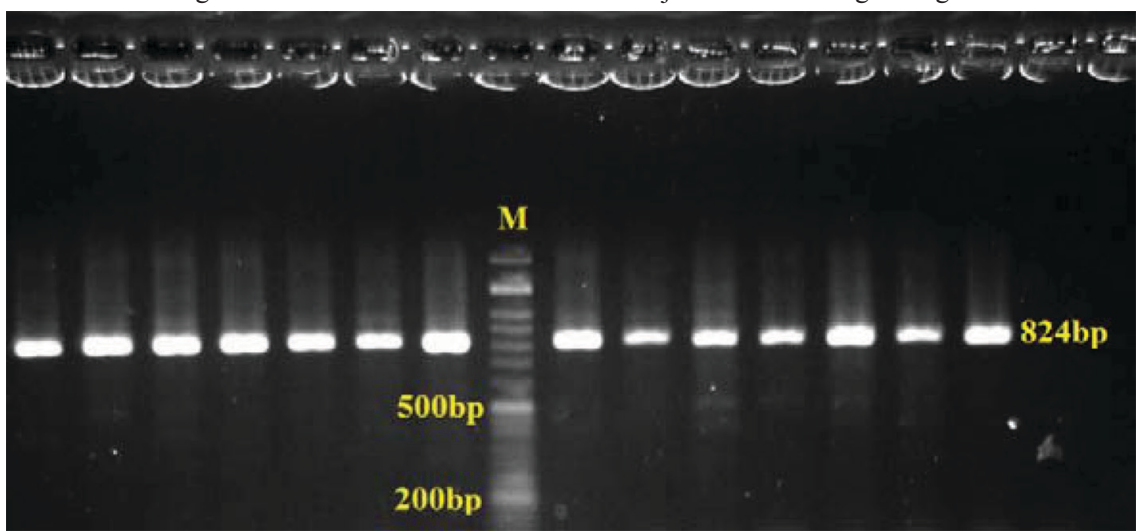

Figure 2. Amplification of exon II of MTNR1A gene (824bp) on 1\% agarose gel. M: 50bp Ladder marker 


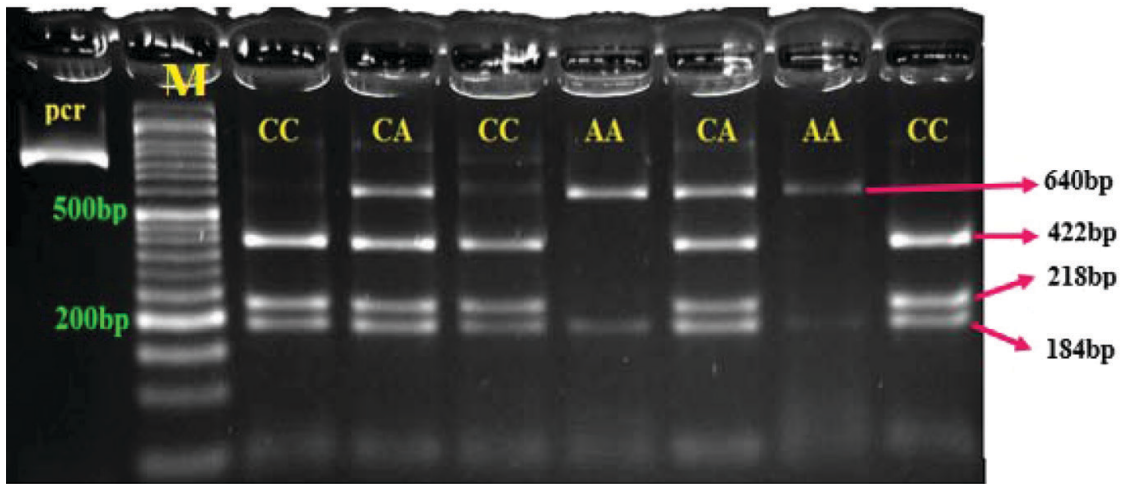

Figure 3. Digestion of $824 \mathrm{bp}$ fragment of MTNR1A gene using SsiI enzyme on 3\% agarose gel. AA (640 and 184bp), CA (640, 422, 218 and 184bp), CC (422, 218 and 184bp) genotypes

A 517 bp fragment including promoter 2 (P2) at CYP19 gene was amplified for all samples (Figure 4). Digestion of amplicons by DraI restriction enzyme showed presence of $A$ to $G$ mutation located in position 113 of the sequence (GenBank AJ012144). PCR-RFLP results detected two alleles (A and $G$ ) and two genotypes (AA: 401, $116 \mathrm{bp}$ and AG: 517, 116, $401 \mathrm{bp}$ ) in the studied population (Figure 5). The estimated frequencies of the $A$ and $G$ alleles were 0.95 and 0.05 and those for the AA and AG genotypes were 0.89 and 0.11 , respectively (Table 2).

Table 2. The genotypes and allele frequencies of MTNR1A and CYP19 genes polymorphisms and Chi-square values in Sanjabi sheep rams

\begin{tabular}{l|cc|c|c}
\hline Gene & Allele frequency & Genotype frequency & $\begin{array}{c}\text { Chi-square } \\
\text { (P-value) }\end{array}$ \\
\hline MTNR1A & $\mathrm{C}=0.65$ & $\mathrm{~A}=0.35$ & $\mathrm{CC}(43)=0.45$ & 1.18 \\
& & $\mathrm{CA}(39)=0.41$ & $(0.27)$ \\
& & $\mathrm{AA}(14)=0.14$ & \\
\hline CYP19 & $\mathrm{A}=0.95$ & $\mathrm{G}=0.05$ & $\mathrm{AA}(85)=0.89$ & 0.32 \\
& & $\mathrm{AG}(11)=0.11$ & $(0.57)$ \\
\hline
\end{tabular}

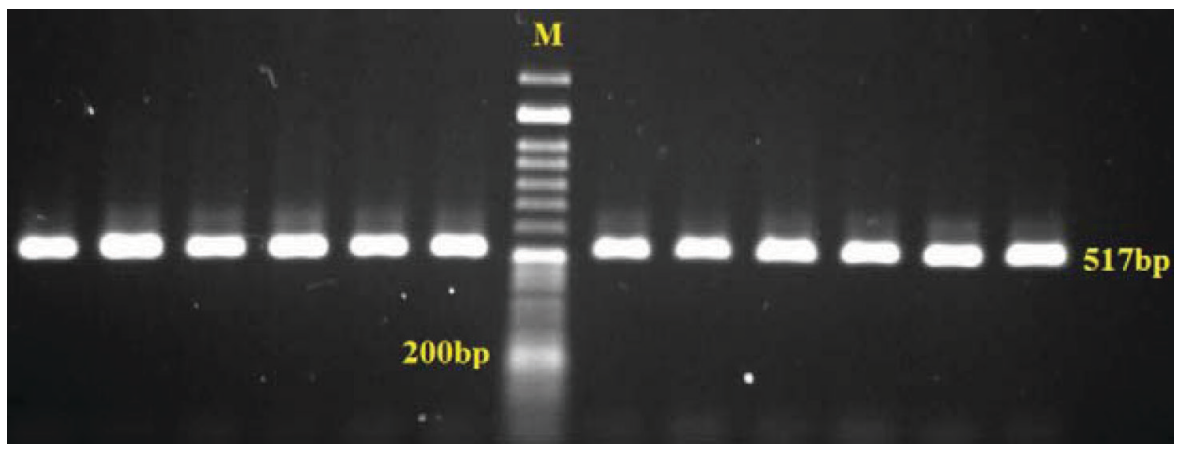

Figure 4. Amplification of p2 of CYP19 gene (517bp) on 1\% agarose gel. M: 50bp Ladder marker 


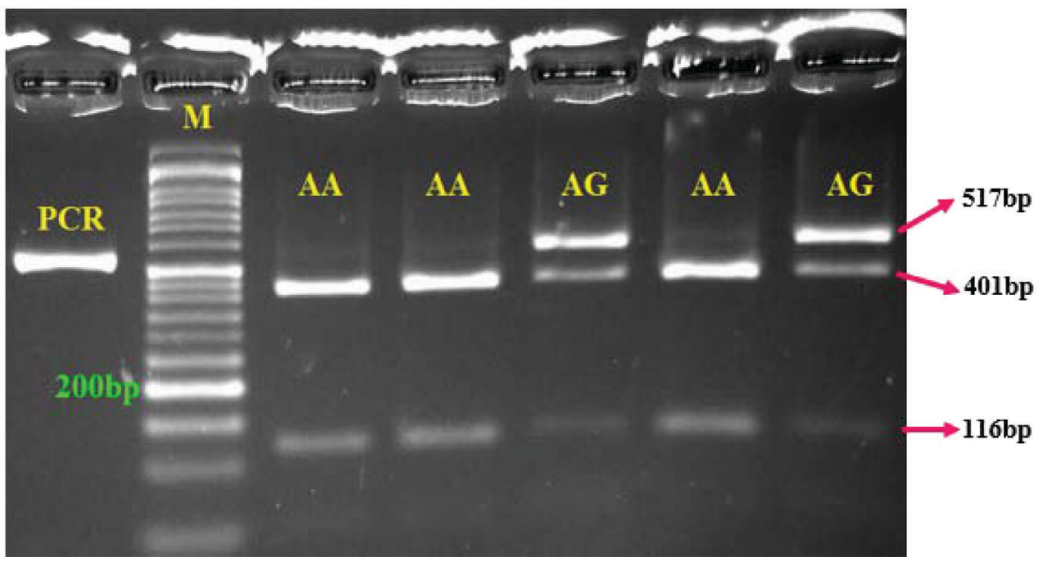

Figure 5. Digestion of 517bp PCR product of CYP19 gene using DraI enzyme on 3\% agarose gel. AA (401 and 116bp), AG (517, 116 and 401bp) genotypes

The result of Chi-square test (Table 2) indicated that the population of Sanjabi native sheep for these genes was in Hardy-Weinberg equilibrium $(\mathrm{P}>0.05)$, which can be a sign of absence of selection and immigration in the local herds. Population diversity indexes for these positions were shown in Table 3. For MTNR1A gene, Shannon and Nei index amounts were calculated (0.646 and 0.454, respectively), which show high genetic variation in this population. However, these indexes for CYP19 gene were estimated to be 0.108 and 0.219 , respectively (Table 3 ), which reveal moderate genetic diversity of $C Y P 19$ gene in the present population.

Table 3. The estimation of population diversity indexes in Sanjabi breed rams

\begin{tabular}{l|c|c|c|c|c|cc}
\hline \multicolumn{1}{c|}{ Gene } & Ob-Hom & Ob-Het & Exp-Hom & Exp-Het & Ne & Nei & I \\
\hline MTNR1A & 0.593 & 0.406 & 0.543 & 0.456 & 1.832 & 0.454 & 0.646 \\
CYP19 & 0.885 & 0.114 & 0.891 & 0.108 & 1.121 & 0.108 & 0.219 \\
\hline
\end{tabular}

Ob-Hom = Observed Homozygosity, Exp-Hom = Expected Homozygosity, Ob-Het = Observed Heterozygosity, Exp-Het = Expected Heterozygosity, $\mathrm{Ne}=$ Effective number of alleles, Nei = Nei's genetic diversity, $\mathrm{I}=$ Shannon's Information Index.

\section{Association of MTNR1A and CYP19 genes polymorphisms with testicular size traits}

Results of relationship between polymorphisms observed in exon II of MTNR1A gene and in promoter $2\left(\mathrm{P}_{2}\right)$ of CYP19 gene with testicular size traits are presented in Table 4. Statistical analysis indicated no significant effect of different genotypes at MTNR1A gene on the testicular size traits (Table 4) but the AA genotype had the highest average of the testicular length, scrotal circumference and testicular volume.

The results showed a significant association between $C Y P 19$ gene polymorphism and scrotal circumference $(\mathrm{P}<0.05)$, as AA genotype had the higher scrotal circumference than that of AG genotype. More significant associations were not observed between this polymorphism and other testicular size traits. 
Table 4. Least square means ( \pm standard error) of MTNR1A and CYP19 genotypes for testicular size in Sanjabi rams

\begin{tabular}{c|c|c|c|c|c}
\hline Gene & Genotype & TL $(\mathrm{cm})$ & TW $(\mathrm{cm})$ & \multicolumn{1}{c}{ TV $(\mathrm{cm})$} & SC $(\mathrm{cm})$ \\
\hline MTNR1A & CC & $18.69 \pm 0.65$ & $7.47 \pm 0.27$ & $123.54 \pm 8.31$ & $31.20 \pm 1.06$ \\
& CA & $19.21 \pm 0.57$ & $7.5 \pm 0.25$ & $122.97 \pm 7.7$ & $31.86 \pm 0.98$ \\
& AA & $19.30 \pm 0.97$ & $7.38 \pm 0.4$ & $129.04 \pm 12.39$ & $31.84 \pm 1.48$ \\
\hline CYP19 & AA & $18.64 \pm 0.38$ & $7.66 \pm 0.19$ & $131.64 \pm 5.89$ & $32.98 \pm 0.86 \mathrm{a}$ \\
& AG & $19.49 \pm 0.96$ & $7.24 \pm 0.4$ & $118.73 \pm 12.32$ & $30.35 \pm 1.47 \mathrm{~b}$ \\
\hline
\end{tabular}

TL: Testicular Length, TW: Testicular Width, TV: Testicular Volume, SC: Scrotal circumference. $\mathrm{a}, \mathrm{b}-$ means in the column of each parameter with different letters differ significantly $(\mathrm{P}<0.05)$.

\section{Association of MTNR1A and $C Y P 19$ genes polymorphisms with sperm qual- ity traits}

In the present study, the effect of different genotypes at C893A position of MT$N R 1 A$ gene on sperm quality traits in Sanjabi sheep breed was evaluated for the first time. Our results showed a significant association between MTNR1A genotypes and morphological traits $(\mathrm{P}<0.05)$, as the $\mathrm{CA}$ and $\mathrm{CC}$ genotypes had the highest and lowest rate of normal morphology, respectively, however there was no significant association between these genotypes and other traits of sperm quality (Table 5).

Table 5. Least square means ( \pm standard error) of $M T N R 1 A$ genotypes for sperm quality in Sanjabi

\begin{tabular}{c|c|c|c|c|c}
\multicolumn{7}{c}{ rams } \\
\hline \multirow{2}{*}{ Genotype } & $\begin{array}{c}\text { SV } \\
(\mathrm{ml})\end{array}$ & $\begin{array}{c}\text { GM } \\
(0-5)\end{array}$ & $\begin{array}{c}\text { PM } \\
(\%)\end{array}$ & $\begin{array}{c}\text { SCON } \\
(\mathrm{X} \times 107)\end{array}$ & $\begin{array}{c}\text { TSE } \\
(\mathrm{X} \times 107)\end{array}$ \\
\hline CC & $1.31 \pm 0.12$ & $1.52 \pm 0.1$ & $4.44 \pm 0.045$ & $265.12 \pm 32.12$ & $337.83 \pm 56.8$ \\
CA & $1.32 \pm 0.1$ & $1.56 \pm 0.09$ & $4.4 \pm 0.042$ & $270.62 \pm 27.86$ & $371.67 \pm 48.06$ \\
AA & $1.12 \pm 0.17$ & $1.56 \pm 0.14$ & $4.45 \pm 0.06$ & $231.88 \pm 44.81$ & $256.82 \pm 87.11$ \\
\hline \multirow{2}{*}{ Genotype } & SMO & SI & SVIA & WT & HOS \\
& $(\%)$ & $\left(\mathrm{ml}^{-1}\right)$ & $(\%)$ & $(\%)$ & $(\%)$ \\
\hline CC & $88.25 \pm 1.99 \mathrm{~b}$ & 2489000.08 & $85.86 \pm 2.43$ & $89.08 \pm 1.95$ & $94.48 \pm 1.41$ \\
CA & $92.75 \pm 1.78 \mathrm{a}$ & 2796146.40 & $82.93 \pm 2.24$ & $89.00 \pm 1.79$ & $93.40 \pm 1.31$ \\
AA & $90.30 \pm 2.56 \mathrm{ab}$ & 1698477.88 & $83.68 \pm 3.41$ & $89.98 \pm 2.7$ & $92.85 \pm 2.03$ \\
\hline
\end{tabular}

SV: Sperm Volume, GM: Gross Motility, PM: Progressive Motility, SCON: Sperm Concentration, TSE: Total spermatozoa per ejaculate, SMO: Sperm Morphology, SI: Sperm Index, SVIA: Sperm Viability, WT: Water Test, HOS: Hypo Osmotic Swelling Test.

$\mathrm{a}, \mathrm{b}, \mathrm{c}-$ means in the column of each parameter with different letters differ significantly $(\mathrm{P}<0.05)$.

Table 6. Least square means ( \pm standard error) of CYP19 genotypes for sperm quality in Sanjabi rams

\begin{tabular}{c|c|c|c|c|c}
\hline Genotype & $\begin{array}{c}\text { SV } \\
(\mathrm{ml})\end{array}$ & $\begin{array}{c}\text { GM } \\
(0-5)\end{array}$ & $\begin{array}{c}\text { PM } \\
(\%)\end{array}$ & $\begin{array}{c}\text { SCON } \\
(\mathrm{X} \times 107)\end{array}$ & $\begin{array}{c}\text { TSE } \\
(\mathrm{X} \times 107)\end{array}$ \\
\hline AA & $1.26 \pm 0.07$ & $1.52 \pm 0.06$ & $4.42 \pm 0.03$ & $262.00 \pm 23.8$ & $318.48 \pm 35.1$ \\
AG & $1.25 \pm 0.17$ & $1.58 \pm 0.14$ & $4.46 \pm 0.06$ & $249.75 \pm 42.67$ & $325.73 \pm 80.61$ \\
\hline \multirow{2}{*}{ Genotype } & SMO & $\begin{array}{c}\text { SI } \\
\left(\mathrm{ml}^{-1}\right)\end{array}$ & $\begin{array}{c}\text { SVIA } \\
(\%)\end{array}$ & $\begin{array}{c}\text { WT } \\
(\%)\end{array}$ & $\begin{array}{c}\text { HOS } \\
(\%)\end{array}$ \\
\hline AA & $90.81 \pm 1.63$ & 2510651.65 & $84.92 \pm 1.67$ & $87.80 \pm 1.34$ & $93.85 \pm 0.97$ \\
AG & $90.06 \pm 2.55$ & 2145097.92 & $83.40 \pm 3.46$ & $90.91 \pm 2.77$ & $93.30 \pm 2.03$ \\
\hline
\end{tabular}

SV: Sperm Volume, GM: Gross Motility, PM: Progressive Motility, SCON: Sperm Concentration, TSE: Total spermatozoa per ejaculate, SMO: Sperm Morphology, SI: Sperm Index, SVIA: Sperm Viability, WT: Water Test, HOS: Hypo Osmotic Swelling Test. 
The effect of CYP19 promoter $2\left(\mathrm{P}_{2}\right)$ polymorphism on sperm quality has been shown in Table 6. No significant correlation was observed between CYP19 gene genotypes and sperm quality traits in Sanjabi rams $(\mathrm{P}>0.05)$.

\section{Discussion}

In the present research, recessive homozygous genotype (GG) was not observed in this position of CYP19 gene, which may be due to low frequency of the G allele (0.05) and also small sample size in this study. Based on our results, the frequency of A allele in this breed was higher than $\mathrm{G}$ allele for CYP19 gene, which is in agreement with previous studies in eight breeds from Spanish and Hungarian sheep (Zsolnai et al., 2002) and eight native breeds from Turkish sheep (Elmaci et al., 2013).

Measurement of testis is used as an indicator to determine reproductive status and spermatogenesis capacity of small ruminants such as sheep and goats (Roca et al., 1991). The testicular size parameter is important because it is highly heritable, therefore it can easily be improved by selection (Hafez et al., 1955). A good measurement of testis scrotal circumference (SC), testicular weight (TW), testicular length (TL) and testicular volume (TV) can reliably predict sperm production capacity (Ugwu, 2009). Among these parameters, SC is mostly used because it is easy to be measured and it shows significant positive correlation with TW and sperm concentration (Brito et al., 2004; Al-Ghalban et al., 2004). Generally, a positive correlation exists between SC, TW, percentage of seminiferous tubules and elongated spermatids (Al-Ghalban et al., 2004). Coe (1999) found a significant correlation between SC and semen quality, however, Fernandez et al. (2004) observed no significant relationship between testicular size and sperm production.

Results of the present research showed that different genotypes of CYP19 gene could significantly affect the scrotal circumference trait $(\mathrm{P}<0.05)$, while significant effects were not observed for different genotypes of MTNR1A gene on the testicular size traits $(\mathrm{P}>0.05)$. However, according to previous studies, treatment of rams with implanted melatonin by effecting on hypothalamic pulse producers caused an increase in LH pulse frequency and testicular development (Webster et al., 1991).

Sperm concentration, motility and morphology are used for male infertility realization but sperm morphology alone has been a strict criterion for assessing fertile and infertile men and pregnancy rate in women (Guzick et al., 2001). Nayak and Gunasheela (2016) reported that less than 10 percent normal form of sperm has led to decrease pregnancy rates. Recent data has shown that planted melatonin in non-reproductive season has a significant effect on sperm motility and causes an increase in normal morphology rate in rams (Kaya et al., 2000). Furthermore, Casao et al. (2010) reported that planted melatonin or short-day exposure due to an increase in sperm motility can improve direct effect of melatonin on ram spermatozoa and change in secretion of gonadotrophins (increased secretion of FSH, LH and testosterone), because of an increase in GnRH secretion. 
Our results showed a significant association between genotypes of $M T N R 1 A$ gene and sperm morphological trait $(\mathrm{P}<0.05)$. To our best knowledge, no study to date has been conducted in order to investigate effects of MTNR $1 A$ gene polymorphisms on sperm quality, so there is no possibility to compare our results with previous studies. However, the MTNR1A gene can be one of the possible candidate genes for controlling ovine reproduction. In several studies, two SNPs in sheep MTNR1A gene, at 606 and 612 positions of exon II, had been detected to be associated with seasonal reproduction activity, as reported in different breeds including: Merino d'Arles (Pelletier et al., 2000), Small tail Han (Chu et al., 2006), Sarda (Carcangiu et al., 2009), Chokla (Saxena et al., 2014), and local Greek sheep breed (Giantsis et al., 2016). However, no significant correlation has been found between polymorphism in this gene and seasonal reproduction in Alpine and Creole goat breeds and Ile de France sheep (Migaud et al., 2002; Hernandez et al., 2005).

In the current study, no significant correlation was observed between CYP19 gene genotypes and sperm quality traits $(\mathrm{P}>0.05)$ while the previous researchers have shown presence of that aromatase mRNA in Leydig, Sertoli, spermatocytes and spermatids cells (Carreau and Galeraud-Denis, 2008) and also in human ejaculated spermatozoa (Aquila et al., 2002). Furthermore, previous studies reported that aromatase deficiency in human reduces sperm number and motility (Carreau and Galeraud-Denis, 2008). The results of another study proved a significant association between $C Y P 19$ (TTTA) $)_{7}$ polymorphism and low sperm concentration and motility in normozoospermic men (Lazaros et al., 2011). Additionally, some mutations in CYP19 gene led to estrogen (Maffei et al., 2004) and ER $\alpha$ (Smith et al., 1995) hormone deficiency which caused a reduction in sperm motility and viability.

\section{Conclusions}

In the present research, polymorphisms studied in MTNR1A and CYP19 genes were not associated with most traits of sperm quality and testicular size. The results showed that these polymorphisms cannot be responsible for controlling spermatogenesis. Regarding the role of melatonin and aromatase in reproductive process, it seems that further studies are necessary in order to investigate association of other polymorphism regions in these genes with reproductive traits in the rams.

\section{Acknowledgements}

This work was supported by Razi University (Project No. 2361325), Iran. Also, authors would like to thank Dr. Mojtaba Goli (Faculty of Veterinary Medicine, Razi University, Iran) for his helpful comments on the manuscript.

\section{References}

A 1 - Ghalban A.M., Tabba a M.J., Kridli R.T. (2004). Factors affecting semen characteristics and scrotal circumference in Damascus bucks. Small Rumin. Res., 53: 141-149.

Aquila S., Sisci D., Gentile M., Middea E., Siciliano L., Andò S. (2002). Human ejaculated spermatozoa contain active P450 aromatase. J. Clin. Endocrinol. Metab., 87: 3385-3390. 
Bakhtiar R., Abdolmohammadi A., Hajarian H., Nikousefat Z., Kalantar- N e y e st a naki D. (2017 a). Identification of g. 170G $>$ A and g.332G $>$ A mutations in exon 3 of leptin gene (Bcnl and Cail) and their association with semen quality and testicular dimensions in Sanjabi rams. Anim. Reprod. Sci., 179 (Supplement C): 49-56.

Bakhtiar R., Abdolmohammadi A., Hajarian H., Nikousefat Z., Kalantar- N e ye st a naki D. (2017 b). Investigation of the $5^{\prime}$ flanking region and exon 3 polymorphisms of IGF-1 gene showed moderate association with semen quality in Sanjabi breed rams. Theriogenology., 104 (Supplement C): 186-191.

B ri to L.F., S i lv a A.E., Un a n i a n M.M., D o d e M.A., B a r b o s a R.T., K a s te li c J.P. (2004). Sexual development in early- and late-maturing Bos indicus and Bos indicus $\times$ Bos taurus crossbred bulls in Brazil. Theriogenology, 62: 1198-1217.

Carcangiu V., Mura M.C., Vacca G.M., Pazzola M., Dettori M.L., Luridiana S., B in i P.P. (2009). Polymorphism of the melatonin receptor MT1 gene and its relationship with seasonal reproductive activity in the Sarda sheep breed. Anim. Reprod. Sci., 116: 65-72.

Carre a u S., G a l e ra u d - D e n is I. (2008). Aromatase and estrogens in man reproduction: a review and latest advances. Adv. Med. Sci., 53: 139.

Ca s a o A., Vega S., Pa la cín I., Pérez-P e R., L a viña A., Qu intín F., S evilla E., A be c i a J., Cebrián-Pérez J., F or c a d a F. (2010). Effects of melatonin implants during nonbreeding season on sperm motility and reproductive parameters in Rasa Aragonesa rams. Reprod. Domest. Anim., 45: 425-432.

Chu M., Cheng D., Liu W., Fang L., Ye S. (2006). Association between melatonin receptor 1A gene and expression of reproductive seasonality in sheep. Asian Austral. J. Anim. Sci., 19: 1079 .

C o e P. (1999). Associations among age, scrotal circumference, and proportion of morphologically normal spermatozoa in young beef bulls during an initial breeding soundness examination. J. Am. Vet. Med. Assoc., 214: 1664-1667.

Davids on J., F a rver T. (1980). Conception rates of Holstein bulls for artificial insemination on a California dairy. J. Dairy Sci., 63: 621-626.

E $1 \mathrm{~m}$ a c i C., S a h in S., On er Y. (2013). Distribution of different alleles of aromatase cytochrome P450 (CYP19) and melatonin receptor 1A (MTRN1A) genes among native Turkish sheep breeds. Kafkas Univ. Vet. Fak. Derg., 19: 929-933.

Ev a n s G., M a x w e 11 W.C. (1987). Editors. Collection of semen. In: Salamon's Artificial Insemination of Sheep and Goats. Sydney, Butterworth, Press, pp. 85-91.

Fernandez M., Giráld ez F.J., Frutos P., Laví n P., Mantecon A. (2004). Effect of undegradable protein supply on testicular size, spermiogram parameters and sexual behavior of mature Assaf rams. Theriogenology, 62: 299-310.

Giants is I.A., Lali o t is G.P., S to upa O., Avdi M. (2016). Polymorphism of the melatonin receptor 1A (MNTR1A) gene and association with seasonality of reproductive activity in a local Greek sheep breed. J. Biol. Res. (Thessalon), 23: 9.

Goldammer T., Brunner R.,Vanselow J., Zsolnai A., Fürbass R., Schwerin M. (1999). Assignment of the bovine aromatase encoding gene CYP19 to 10q26 in goat and 7q24 $\rightarrow$ q31 in sheep. Cytogenet Genome Res., 85: 258-259.

Guzick D.S., Overstreet J.W., Factor-Litvak P., Brazil C.K., Nakajima S.T., Coutifaris C., Carson S.A., Cisneros P., Steinkampf M.P., Hill J.A. (2001). Sperm morphology, motility, and concentration in fertile and infertile men. N. Engl. J. Med., 345: 1388-1393.

Hafez E., B a dreldin A., Darw is h Y. (1955). Seasonal variations in semen characteristics of sheep in the subtropics. Asian. J. Agric. Food Sci., 45: 283-292.

Hernandez X., B o d in L., Chesneau D., Guillaume D., Chemineau P., Malpaux B., Mi g a u d M. (2005). Relationship between MT1 melatonin receptor gene polymorphism and seasonal physiological responses in Ile-de-France ewes. Reprod. Nutr. Dev., 45: 151-162.

Javanmard A., Azadzadeh N., Esmailizadeh A.K. (2011). Mutations in bone morphogenetic protein 15 and growth differentiation factor 9 genes are associated with increased litter size in fat-tailed sheep breeds. Vet. Res. Commun., 35: 157-167.

Jones M.E.,Thorburn A.W., Britt K.L., Hewitt K.N., Wreford N.G., Proietto J., 
O z O.K., Le ury B.J., R oberts on K.M.,Ya o S. (2000). Aromatase-deficient (ArKO) mice have a phenotype of increased adiposity. Proc. Natl. Acad. Sci. USA, 97: 12735-12740.

Ka y a A., B a sp in ar N.,Yild i z C., Kurtogl u F., A t a ma n M., Halil oglu S. (2000). Influence of melatonin implantation on sperm quality, biochemical composition of the seminal plasma and plasma testosterone levels in rams. Rev. Med. Vet. (Toulouse), 151: 1143-1146.

Lang ford G., A insw orth L., Marcus G., Shrestha J. (1987). Photoperiod entrainment of testosterone, luteinizing hormone, follicle-stimulating hormone, and prolactin cycles in rams in relation to testis size and semen quality. Biol. Reprod., 37: 489-499.

Lazaros L., Xit a N., Ka pon is A., Hatzi E., P la chouras N., S ofikitis N., Zikopoulos K., G e orgiou I. (2011). The association of aromatase (CYP19) gene variants with sperm concentration and motility. Asian. J. Androl., 13: 292.

Maffei L., Murata Y., Rochira V., Tubert G., Aranda C., Vazquez M., Clyne C.D., Davis S., S i m p s on E.R., C a r a n i C. (2004). Dysmetabolic syndrome in a man with a novel mutation of the aromatase gene: effects of testosterone, alendronate, and estradiol treatment. J. Clin. Endocrinol. Metab., 89: 61-70.

M a l pa ux B., Th iéry J.-C., C h e m in e a u P. (1999). Melatonin and the seasonal control of reproduction. Reprod. Nutr. Dev., 39: 355-366.

Mathevon M., Buhr M., Dekkers J. (1998). Environmental, management, and genetic factors affecting semen production in Holstein bulls. J. Dairy Sci., 81: 3321-3330.

Mess e r L.A.,Wang L., Tugg le C.K., Yerle M., Chardon P., Pomp D., Wo m a ck J.E., B arend s e W., C r aw ford A.M., N ot ter D.R. (1997). Mapping of the melatonin receptor la (MTNR1A) gene in pigs, sheep, and cattle. Mamm. Genome., 8: 368-370.

Mi a M., Khandoker M., Hus a in S., F aruque M., Notter D., A pu A. (2015). Genetic and phenotypic parameters for semen characteristics and their relationship with scrotal circumference in Black Bengal bucks. Iran J. Appl. Anim. Sci., 3: 709-717.

Mig a u d M., G a v e t S., P e 11 e t i e r J. (2002). Partial cloning and polymorphism of the melatonin 1a (Mel1a) receptor gene in two breeds of goat with different reproductive seasonality. Reproduction, 124: 59-64.

Muka s a - M u gerwa E., E z a z Z. (1992). Relationship of testicular growth and size to age, body weight and onset of puberty in Menz ram lambs. Theriogenology, 38: 979-988.

N a y a k V., Gun a sh e ela D. (2016). Relationship of sperm morphology assessed by strict criteria and outcome of artificial [intrauterine] insemination. Int. J. Reprod. Contracept. Obstet. Gynecol., 2: 58-60.

Nur Z., D o gan I., Gun ay U., S o y lu M.K. (2005). Relationships between sperm membrane integrity and other semen quality characteristics of the semen of saanen goat bucks. Bull Vet. Inst. Pulawy, 49: 183-187.

Pelletier J., Bodin L., Hanocq E., Malpaux B., Teyssier J., Thimonier J., $\mathrm{Ch}$ e m in e a P P. (2000). Association between expression of reproductive seasonality and alleles of the gene for Mella receptor in the ewe. Biol. Reprod., 62: 1096-1101.

Rege J., Toe F., Mukas a-Mugerwa E., Tembely S., Anindo D., Baker R., Lahlou- Ka s s i A. (2000). Reproductive characteristics of Ethiopian highland sheep: II. Genetic parameters of semen characteristics and their relationships with testicular measurements in ram lambs. Small Rumin. Res., 37: 173-187.

R e p p e r t S.M., We a v e r D.R., E b i s a w a T. (1994). Cloning and characterization of a mammalian melatonin receptor that mediates reproductive and circadian responses. Neuron., 13: 1177-1185.

Revel1 S., Mrode R. (1994). An osmotic resistance test for bovine semen. Anim. Reprod. Sci., 36: $77-86$.

R o c a J., Martine z E., Va z que z J., R u i z S., C o y P. (1991). Influence of season on testicle size and libido in male goats from the Mediterranean area. Anim. Prod., 52: 317-321.

SAS Institute (2004). SAS User's Guide Version 9.1: Statistics. Cary, NC: SAS Institute Inc.

S a x e n a V.K., Jha B.K., M e en a A.S., N a qvi S. (2014). Sequence analysis and identification of new variations in the coding sequence of melatonin receptor gene (MTNR1A) of Indian Chokla sheep breed. Meta Gene, 2: 450-458.

Simpson E.R., Mahendroo M.S., Means G.D., Kilgore M.W., Hins helwood M.M., Graham-Lorence S., Amarneh B., Ito Y., Fisher C.R., Michael M.D. (1994). 
Aromatase cytochrome P450, the enzyme responsible for estrogen biosynthesis. Endocr. Rev., 15: 342-355.

S impson E., Rubin G., C1 yn e C., Roberts on K., O ' Donnell L., Jon es M., D a vis S. (2000). The role of local estrogen biosynthesis in males and females. Trends Endocrinol. Metab., 11: 184-188.

Smith E.P., Boyd J., Frank G.R., Takahashi H., Cohen R.M., Specker B., Wil$1 \mathrm{i}$ a $\mathrm{m} \mathrm{s}$ T.C., L u b a h D.B., K or a ch K.S. (1995). Estrogen resistance caused by a mutation in the estrogen-receptor gene in a man. Obstet Gynecol Surv., 50: 201-204.

Ugwu S. (2009). Relationship between scrotal circumference, in situ testicular measurements and sperm reserves in the West African dwarf bucks. Afr. J. Biotechnol., 8: 1354.

Van se low J., F ürbas s R., Z s olna i A., K a lb e C., S a id H.M., S chwerin M. (2001). Expression of the aromatase cytochrome P450 encoding gene in cattle and sheep. J. Steroid Biochem. Mol. Biol., 79: 279-288.

Webster J., Suttie J., Veenvliet B., Manley T., Littlejohn R. (1991). Effect of melatonin implants on secretion of luteinizing hormone in intact and castrated rams. J. Reprod. Fertil., 92: 21-31.

Yeh F.C., Yang R.C., B oyle T.B.J., Ye Z.H., Ma o J.X. (1999). POPGENE, the user-friendly shareware for population genetic analysis. Canada: Molecular Biology and Biotechnology Centre, University of Alberta. Edmonton, AB, Canada: University of Alberta.

Z solnai A., Anton I., Fés üs L., Eston ba A., S chwerin M., Van selow J. (2002). Allele distributions of two novel SNPs within the sheep Cyp19 gene. J. Anim. Breed Genet., 119: 402-405.

Received: 8 XII 2017

Accepted: 25 IV 2018 